\title{
PENERAPAN BALANCED SCORECARD \\ UNTUK BADAN PENELITIAN DAN PENGEMBANGAN KEMENTERIAN DALAM NEGERI
}

\section{THE APPLICATION OF BALANCED SCORECARD FOR BADAN PENELITIAN DAN PENGEMBANGAN KEMENTERIAN DALAM NEGERI}

\author{
Teguh Narutomo \\ Pusat Penelitian dan Pengembangan Kesatuan Bangsa, Politik dan Otonomi Daerah \\ Badan Penelitian dan Pengembangan (BPP) Kementerian Dalam Negeri \\ Jalan Kramat Raya No. 132, Senen - Jakarta Pusat \\ e-mail: narutomo_litbang@yahoo.com \\ Diterima: 16 Juli 2012; direvisi: 23 Juli 2012; disetujui: 10 Agustus 2012
}

\begin{abstract}
Abstrak
Balance Scorecard dapat menuntun manajemen dan anggota organisasi dalam menterjemahkan visi, misi serta strategi organisasi ke dalam tindakan yang nyata. Dalam Balanced Scorecard, pengukuran kinerja dilihat dari 4 perspektif yaitu Customer and Stakeholder Perspective, Financial Perspective, Employees and Organization Capacity Perspective, dan Internal Bussiness Process Perspective. Pengukuran kinerja dengan pendekatan Balanced Scorecard tidak terbatas digunakan pada organisasi swasta melainkan juga bisa diterapkan pada organisasi sektor publik. Tulisan ini menguraikan tentang perlunya Balanced Scorecard untuk organisasi pemerintah dan peluangnya apabila digunakan di Badan Penelitian dan Pengembangan (BPP) Kementerian Dalam Negeri (Kemendagri) berdasarkan beberapa analisis dan hasil penelitian yang pernah dilakukan.
\end{abstract}

Kata kunci: penilaian kinerja, pemerintah, balanced scorecard,BPP Kemendagri.

\begin{abstract}
Balance Scorecard to guide the management and members of the organization in translating the vision, mission and strategy of the organization into the real action. In the Balanced Scorecard performance measurement viewed from four perspectives, namely Customer and Stakeholder Perspective, Financial Perspective, Employees and Organization Capacity Perspective and Bussiness Internal Process Perspective. Measuring the performance of the Balanced Scorecard approach is not limited to use in private organizations but also can be applied to public sector organizations. This paper describes the need for Balanced Scorecard for government organizations and opportunities when used in BPP Kemendagri based on some analysis and results of studies that have been conducted
\end{abstract}

Keywords: performance appraisal, government, balanced scorecard, BPP Kemendagri.

\section{PENDAHULUAN}

Balanced scorecard sebagai alat akuntansi manajemen telah berkembang dari suatu sistem pengukuran kinerja menjadi suatu sistem manajemen strategi. Hal ini berarti organisasi swasta maupun organisasi pemerintah yang inovatif dapat menggunakan balanced scorecard tidak hanya untuk menjelaskan dan mengkomunikasikan strategi, melainkan juga untuk mengelola strateginya dalam jangka panjang.

Sistem manajemen strategis adalah proses merumuskan dan mengimplementasikan strategi untuk mewujudkan visi secara terus menerus secara terstruktur. Strategi adalah pola tindakan terpilih untuk mencapai tujuan tertentu. Pada mulanya, sistem manajemen strategis bercirikan: mengandalkan anggaran tahunan, berjangka panjang dan berfokus pada kinerja keuangan. Penerapan sistem manajemen strategis yang demikian di banyak perusahaan swasta mengalami kegagalan. Namun sistem manajemen strategis tetap diperlukan karena perusahaan dituntut untuk berkembang secara terencana dan terukur, sehingga memerlukan peta perjalanan menghadapi masa depan yang tidak pasti, memerlukan langkahlangkah strategis, dan perlu mengarahkan kemampuan dan komitmen SDM untuk mewujudkan tujuan perusahaan.

Peran balanced scorecard dalam sistem manajemen strategis adalah: memperluas perspektif dalam setiap tahap sistem manajemen strategis, membuat fokus manajemen menjadi seimbang, mengaitkan berbagai sasaran secara koheren, dan mengukur kinerja secara kuantitatif. Penggunaan balanced scorecard dalam konteks perusahan swasta ditujukan untuk menghasilkan proses yang produktif 
dan cost effective, menghasilkan financial return yang berlipat ganda dan berjangka panjang, mengembangkan sumber daya manusia yang produktif dan berkomitmen, mewujudkan produk dan jasa yang mampu menghasilkan value terbaik bagi customer/pelanggan.

Balanced scorecard diyakini dapat mengubah strategi menjadi tindakan menjadikan strategi sebagai pusat organisasi, mendorong terjadinya komunikasi yang lebih baik antar karyawan/pegawai dan manajemen, meningkatkan mutu pengambilan keputusan dan memberikan informasi peringatan dini, serta mengubah budaya kerja. Potensi untuk mengubah budaya kerja ada karena dengan balanced scorecard, organisasi lebih transparan, informasi dapat diakses dengan mudah, pembelajaran organisasi dipercepat, umpan balik menjadi obyektif, terjadwal, dan tepat untuk organisasi dan individu; dan membentuk sikap mencari konsensus karena adanya perbedaan awal dalam menentukan sasaran, langkah-langkah strategis yang diambil, ukuran yang digunakan, dll.

Kelebihan sistem manajemen strategis berbasis balanced scorecard dibandingkan konsep manajemen yang lain adalah bahwa ia menunjukkan indikator outcome dan output yang jelas, indikator internal dan eksternal, indikator keuangan dan non-keuangan, dan indikator sebab dan akibat. Balanced scorecard paling tepat disusun pada saat-saat tertentu, ketika akan melaksanakan strategi besar dan ketika organisasi berubah haluan atau akan mendorong proses perubahan. Balanced scorecard juga diterapkan dalam situasisituasi yang rutin, antara lain: pada saat menyusun rencana alokasi anggaran, menyusun manajemen kinerja, melakukan sosialisasi terhadap kebijakan baru, memperoleh umpan balik, meningkatkan kapasitas staf.

Siapa yang menggunakan balanced scorecard? Banyak organisasi swasta, pemerintah dan nirlaba yang telah menggunakan balanced scorecard 60\% dari 1000 organisasi dalam Fortune menggunakan balanced scorecard. Balanced scorecard semakin banyak diadopsi di Eropa, Australia dan Asia oleh organisasi besar, menengah dan kecil. Perusahaan yang menunjukkan keberhasilan luar biasa setelah menerapkan balanced scorecard adalah antara lain: MOBIL Oil yang pada tahun 1993 menempati posisi ke 6 dalam provitability, kemudian menjadi nomor satu pada periode 1995-1998; CIGNA pada tahun 1993 rugi \$275 M, tahun 1994 menjadi untung sebesar \$15 M dan tahun 1997 sebesar \$98 M; BROWN \& ROOT ENG. tahun 1993 rugi namun tahun 1996 menjadi nomor satu dalam pertumbuhan profit.

Kemunculan gagasan balanced scorecard berawal dari temuan riset Kaplan dan Norton (dari Harvard Business School) pada awal tahun 1990an. Konsep awal balanced scorecard berdasarkan riset tersebut ditulis pada tahun 1992 di majalah prestisius Harvard Business Review. Pada tahun 1996 Norton dan Kaplan menerbitkan buku The Balanced Scorecard Translating Strategy into Action, berdasarkan pengalaman mereka dalam menerapkan balanced scorecard pada banyak perusahaan di Amerika. Buku ini semakin mempopulerkan balanced scorecard, sampai ke negara-negara di Eropa, Australia dan Asia. Belum lama ini mereka menerbitkan buku The Strategy Focused Organisation - How BSC Companies Thrive in the New Business Environment (2001). Para penemu dan rekan-rekannya membangun sebuah lembaga Balanced Scorecard Collaboration untuk memopulerkan penggunaan balanced scorecard pada berbagai institusi di berbagai negara. Secara teratur Norton dan Kaplan menyelenggarakan konferensi di berbagai negara untuk memperkenalkan dan membahas konsep-konsep terbaru mereka. Disayangkan Indonesia sampai saat ini belum mampu menghadirkan pencetus ide balanced scorecard ini, namun kursus-kursus dan buku-buku mengenai balanced scorecard sudah ada, walau masih bersifat terbatas.

Balanced scorecard terdiri dari 2 suku kata yaitu kartu nilai (scorecard) dan balanced (berimbang) adalah suatu sistem manajemen untuk mengelola implementasi strategi, mengukur kinerja secara utuh, mengkomunikasikan visi, strategi dan sasaran kepada stakeholders. Kata balanced dalam balanced scorecard merujuk pada konsep keseimbangan antara berbagai perspektif, jangka waktu (pendek dan panjang), lingkup perhatian (intern dan ekstern) artinya (a) Pengukuran kinerja eksternal (masyarakat) dan pengukuran kinerja internal (proses bisnis internal, inovasi, proses belajar dan pertumbuhan); (b) Pengukuran kinerja masa lalu (finansial) dan pengukuran yang mendorong kinerja masa datang (non finansial); (c) Unsur objektivitas (pengukuran berupa hasil kuantitatif) dengan unsur subjektivitas (pengukuran pemicu kinerja yang membutuhkan pertimbangan/ kualitatif); dan (d) Tujuan jangka pendek dan tujuan jangka panjang. Kata scorecard mengacu pada rencana kinerja organisasi dan bagian-bagiannya serta ukurannya secara kuantitatif. Maksudnya adalah kartu nilai untuk mengukur kinerja personil yang dibandingkan dengan kinerja yang direncanakan, serta dapat digunakan sebagai evaluasi.

Balanced scorecard menerjemahkan visi dan strategi organisasi kedalam tujuan konkrit terorganisasi di sepanjang jalur 4 perspektif yang berbeda: finansial, pelanggan, proses internal, dan pembelajaran dan pertumbuhan. Untuk organisasi pemerintah Balanced Scorecard menyediakan jawaban atas empat pertanyaan yang mendasar melalui perspektif, yaitu:

1. How do customers see us? (Customer and Stakeholders Perspective menggantikan Customers Perspective)

2. How do we look to shateholders? (Financial Perspective)

3. Can we continue to improve and create value? (Employee and organisation capacity Perspective menggantikan Learning And Growth Perspective)

4. What must we excel at? (Internal Business Process Perspective)

Selanjutnya dalam menerapkan balanced scorecard, Robert Kaplan dan David Norton, mensyaratkan dipegangnya lima prinsip utama berikut: 
1. Menerjemahkan sistem manajemen strategi berbasis balanced scorecard ke dalam terminologi operasional sehingga semua orang dapat memahami

2. Menghubungkan dan menyelaraskan organisasi dengan strategi itu. Ini untuk memberikan arah dari eksekutif kepada staf garis depan

3. Membuat strategi merupakan pekerjaan bagi semua orang melalui kontribusi setiap orang dalam implementasi strategis

4. Membuat strategi suatu proses terus menerus melalui pembelajaran dan adaptasi organisasi dan

5. Melaksanakan agenda perubahan oleh eksekutif guna memobilisasi perubahan.

Kinerja merujuk pada hasil yang dapat diselesaikan oleh seorang karyawan dalam periode waktu tertentu. Kinerja juga merujuk pada perilaku karyawan dalam bekerja. Hersey dan Blanchard (1993) mendefinisikan kinerja sebagai suatu fungsi dari motivasi dan kemampuan seseorang untuk menyelesaikan tugas atau pekerjaannya. Kinerja adalah hasil seseorang secara keseluruhan selama periode tertentu di dalam melaksanakan tugas, seperti standar hasil kerja, target atau sasaran atau kriteria yang telah ditentukan terlebih dahulu dan telah disepakati bersama (Rivai dan Basri, 2004).

Sejalan dengan definisi-definisi sebelumnya, Robbins (1997) menggambarkan kinerja sebagai fungsi interaksi antara kemampuan (ability), motivasi (motivation) dan kesempatan (opportunity). Kinerja seorang karyawan merupakan hal yang bersifat individual karena setiap karyawan mempunyai tingkat kemampuan yang berbeda dalam melaksanakan tugasnya. Keberhasilan kinerja seseorang diukur dari sejauh mana ia dapat mencapai tujuan yang ditetapkan baginya. Ikopin (2008) juga menyatakan bahwa pengukuran kinerja karyawan identik dengan apakah karyawan mampu melaksanakan tugasnya dengan baik. Artinya, karyawan memiliki tanggung jawab, mampu melaksanakan pekerjaannya tepat waktu dan dapat mencapai target yang telah ditentukan.

Definisi tersebut sejalan dengan apa yang tercantum dalam Instruksi Presiden Nomor 7 Tahun 1999 tentang Akuntabilitas Kinerja Instansi Pemerintah yang menguraikan bahwa Akuntabilitas Kinerja adalah perwujudan kewajiban suatu instansi pemerintah untuk mempertanggungjawabkan keberhasilan/kegagalan pelaksanaan misi organisasi dalam mencapai tujuantujuan dan sasaran-sasaran yang telah ditetapkan melalui alat pertanggungjawaban secara periodik. Demikian pula yang dicantumkan pada Keputusan Kepala Lembaga Administrasi Negara Tanggal 25 Maret 2003 Nomor 239/IX/6/8/2003 tentang Perbaikan Pedoman Penyusunan Pelaporan Akuntabilitas Kinerja Instansi Pemerintah, Undang-Undang Nomor 32 Tahun 2004 tentang Pemerintahan Daerah, Surat Keputusan MENPAN Nomor KEP-135/M.PAN/2004 tentang Pedoman Umum Evaluasi Laporan Akuntabilitas Kinerja Instansi Pemerintah, Peraturan Pemerintah Nomor 8 Tahun 2006 tentang Pelaporan Keuangan dan
Kinerja Instansi Pemerintah, Undang-Undang No. 25 tahun 2009 tentang Pelayanan Publik, Surat Menteri Negara PAN Nomor B/1301/M.PAN/04/2009 Perihal Kebijakan Evaluasi Akuntabilitas Kinerja Tahun 2009, dan Peraturan MENPAN dan Reformasi Birokrasi Nomor 7 Tahun 2010 Tentang Pedoman Penilaian Kinerja Unit Pelayanan Publik.

Pengukuran kinerja organisasi publik merupakan suatu alat perencanaan dan sistem pengendalian manajemen yang bertujuan untuk membantu manajer publik menilai pencapaian suatu strategi melalui alat ukur finansial dan non finansial. Pengukuran kinerja sector publik dilakukan untuk memenuhi tiga maksud. Pertama, pengukuran kinerja sektor publik dimaksudkan untuk memperbaiki kinerja pemerintah. Ukuran kinerja dimaksudkan untuk dapat membantu pemerintah berfokus pada tujuan dan sasaran program unit kerja. Kedua, ukuran kinerja sektor publik digunakan untuk pengalokasian sumber daya dan pembuatan keputusan. Ketiga, ukuran kinerja sektor publik dimaksudkan untuk mewujudkan pertanggungjawaban publik dan memperbaiki komunikasi pelanggan.

Sebagian besar organisasi publik telah menyadari kebutuhan akan pengukuran kinerja dalam instansinya ('bottom-line' performance). Namun pengukuran tersebut masih dilakukan dengan menggunakan sistem tradisional, yaitu pengukuran pencapaian finansial yang didasarkan pada pelaporan keuangan. Padahal, menurut Mulyadi dan Setyawan (1999), ukuran keuangan tidak dapat menggambarkan kondisi riil perusahaan di masa lalu dan tidak mampu menjadi pedoman bagi suatu organisasi ke arah yang lebih baik, serta hanya berorientasi jangka pendek. Jadi, sistem pengukuran kinerja finansial organisasi publik ini lebih dirancang untuk memenuhi kebutuhan shareholders, daripada untuk menyediakan informasi dalam membantu pengelolaan suatu organisasi.

Suatu sistem pengukuran kinerja organisasi publik yang seimbang harus dapat meningkatkan perhatian dan kesejajaran, mempermudah komunikasi, dan menyiapkan suatu visi yang jauh ke depan ( $a$ forward-looking vision), sehingga semua orang dapat termotivasi untuk mengubah perilaku mereka agar sejalan dengan tujuan organisasi publik. Suatu sistem pengukuran yang baik haruslah menyeluruh atau komprehensif, termasuk pengukuran-pengukuran penting dari seluruh bidang operasional maupun dari semua jenis pengukuran. Sistem tersebut juga harus termasuk pengukuran-pengukuran finansial maupun non finansial, indikator-indikator dari hasil di masa lampau dan prediktor-prediktor dari kinerja di masa datang, dan pengukuran-pengukuran yang mencakup faktor waktu, biaya dan kualitas.

Parayudha (2009) menyatakan bahwa desain balanced scorecard mampu meningkatkan manajemen strategis dan tata kelola dalam organisasi publik. Balanced scorecard dapat menciptakan perilaku manajemen umum yang lebih baik melalui persamaan yang kuat antara pendekatan yang diusulkan dan desain 
lainnya, sebagaimana yang diterapkan dalam sektor komersial.

Tujuan pengukuran kinerja sektor publik menurut Mardiasmo (2002: 122) adalah:

1. Mengkomunikasikan strategi secara lebih mantap.

2. Mengukur kinerja finansial dan non-finansial secara berimbang sehingga dapat ditelusuri perkembangan pencapaian strategi.

3. Mengakomodasi pemahaman kepentingan manajer level menengah dan bawah serta memotivasi untuk mencapai goal congruence.

4. Alat untuk mencapai kepuasan berdasarkan pendekatan individual dan kemampuan kolektif rasional.

Manfaat pengukuran kinerja sektor publik menurut Lynch dan Cross (dalam Yuwono, 2002) adalah:

1. Menelusuri kinerja terhadap harapan pelanggan sehingga akan membawa perusahaan lebih dekat kepada pelanggannya dan membuat seluruh orang dalam organisasi terlibat dalam upaya memberi kepuasan kepada pelanggan

2. Memotivasi pegawai untuk melakukan pelayanan sebagai bagian dari mata rantai pelanggan dan pemasok internal.

3. Mengidentifikasi berbagai pemborosan sekaligus mendorong upaya-upaya pengurangan terhadap pemborosan tersebut (reduction of waste).

4. Membuat suatu tujuan strategis yang biasanya masih kabur menjadi lebih konkrit sehingga mempercepat proses pembelajaran.

5. Membangun konsensus untuk melakukan suatu perubahan dengan memberi reward atas perilaku tersebut

\section{PEMBAHASAN}

\section{Balanced Scorecard pada Organisasi Pemerintah}

Mengapa institusi pemerintah perlu mengadopsi balanced scorecard? Pemerintah pada era sekarang ini, baik pemerintah pusat, daerah maupun lokal diharapkan untuk menjadi: akuntabel, kompetitif, ramah, merakyat, dan berfokus pada kinerja. Organisasi pemerintah juga ditantang untuk memenuhi harapan berbagai kelompok stakeholders (yaitu penerima layanan, karyawan, lembaga pemberi pinjaman/hibah, masyarakat, dan pembayar pajak). Tuntutan ini mengharuskan organisasi pemerintah untuk bertindak profesional sebagaimana yang dilakukan oleh organisasi swasta. Organisasi pemerintah harus mempunyai sistem manajemen strategis. Karena dunia eksternal adalah sangat tidak stabil, maka sistem perencanaan harus mengendalikan ketidak-pastian yang ditemui. Organisasi pemerintah, dengan demikian, harus berfokus strategi. Strategi ini lebih bersifat hipotesis, suatu proses yang dinamis, dan merupakan pekerjaan setiap staf. Organisasi pemerintah harus juga merasakan, mengadakan percobaan, belajar, dan menyesuaikan dengan perkembangan.
Agar organisasi pemerintah dapat berfokus pada strategi yang sudah dirumuskan, maka organisasi pemerintah juga harus menterjemahkan strategi ke dalam terminologi operasional, menyelaraskan organisasi dengan strategi (dan bukan sebaliknya), memotivasi staf sehingga membuat strategi merupakan tugas setiap orang, menggerakkan perubahan melalui kepemimpinan eksekutif, dan membuat strategi sebagai suatu proses yang berkesinambungan.

Adapun perbedaan karakteristik organisasi swasta dan pemerintah adalah sebagai mana ditunjukkan dalam tabel berikut.

Tabel 1. Perbedaan Karakteristik Organisasi Swasta dan Pemerintah

\begin{tabular}{|c|c|c|c|}
\hline NO & Perspektif & Swasta & Pemerintah \\
\hline 1 & Finansial & $\begin{array}{l}\text { Pemegang } \\
\text { saham }\end{array}$ & $\begin{array}{l}\text { DPR, pembayar } \\
\text { pajak, konstituen }\end{array}$ \\
\hline 2 & Pelanggan & Pelanggan & $\begin{array}{l}\text { Orang yang } \\
\text { menggunakan } \\
\text { jasa/pelayanan } \\
\text { publik }\end{array}$ \\
\hline 3 & $\begin{array}{l}\text { Proses Proses } \\
\text { Internal }\end{array}$ & $\begin{array}{l}\text { Membuat } \\
\text { produk yang } \\
\text { diunggulkan }\end{array}$ & $\begin{array}{l}\text { Memberikan } \\
\text { pelayanan secara } \\
\text { kompetitif }\end{array}$ \\
\hline 4 & $\begin{array}{l}\text { Pertumbuhan } \\
\& \\
\text { Pembelajaran }\end{array}$ & $\begin{array}{l}\text { karyawan, } \\
\text { direksi }\end{array}$ & $\begin{array}{l}\text { pejabat politik } \\
\text { (menteri), } \\
\text { pegawai } \\
\text { pemerintah }\end{array}$ \\
\hline
\end{tabular}

Cahyono (2000), melakukan penelitian tentang Balanced scorecard di sektor publik. Penelitian tersebut mengambil judul "Pengukuran Kinerja Balanced Scorecard untuk Organisasi Sektor Publik". Hasil penelitian adalah bahwa untuk penilaian kinerja organisasi sektor publik diperlukan banyak pendekatan selain pendekatan keuangan yang menjadi kendala. Secara tidak langsung organisasi sektor publik sudah menerapkan pengukuran kinerja Balanced scorecard akan tetapi belum mengetahui apa yang hendak dipakai dalam mengukur kinerjanya.

Kusuma (2003), melakukan penelitian dengan judul "Penerapan BSC sebagai alat ukur kinerja pada organisasi nirlaba (Studi kasus yayasan setara Semarang). Hasil penelitian tersebut adalah menyebutkan bahwa selama tahun 2000-2002 masingmasing perspektif yang diterapkan pada yayasan tersebut mengalami peningkatan yaitu: perspektif pembelajaran dan pertumbuhan naik sebesar $11 \%$, perspektif proses internal bisnis sebesar 74\%, perspektif pelanggan sebesar $68 \%$ dan perspektif keuangan sebesar $63 \%$.

Herlina (2004), melakukan penelitian dengan judul "analisis penerapan BSC sebagai pengukuran kinerja komprehensif pada perusahaan jasa (studi kasus RS. Roemani Muhammadiyah Semarang). Bahwa rumah sakit masih menggunakan penilaian kinerja yang bersifat tradisional. Dari analisis data dapat diketahui bahwa dari perspektif keuangan mengalami penurunan meski diatas rata-rata, profitabilitas pasien mengalami fluktuasi yang disebabkan peningkatan laba operasional 
dibanding dengan total keuntungan yang didapat, retensi pasien mengalami penurunan yang kemudian meningkat, dalam proses internal bisnis menunjukkan adanya peningkatan jasa pelayanan yang efisien dan efektif.

Perspektif pertumbuhan dan pembelajaran terdapat peningkatan produktivitas karyawan, retensi karyawan juga meningkat. Zakir (2006), melakukan penelitian yang berkaitan dengan balanced scorecard dengan judul "Pengukuran dengan Pendekatan Balanced Scorecard (Studi kasus PT. Bank BPD Jawa Tengah) menunjukkan bahwa pada perspektif keuangan mengalami peningkatan dari tahun sebelumnya, perspektif pelanggan terlihat dari kurang optimalnya pencapaian pelanggan baru selama 3 tahun dan mengalami penurunan yaitu berawal pada tahun 2002, tahun 2003 angka persentase akuisisi pelanggan (pelanggan baru) mengalami penurunan sebesar $25,76 \%$ jika dibandingkan dengan tahun 2002, dan selanjutnya mengalami penurunan yang signifikan pada tahun 2004 yang mencapai 64,71\%. perspektif bisnis internal berhasil melakukan efisiensi biaya operasional mampu meningkatkan pendapatan produk. Perspektif pembelajaran dan pertumbuhan terlihat dari hasil survey menunjukkan kepuasan karyawan dalam kategori cukup puas. Sehingga hasil penelitian tersebut menyebutkan bahwa selama tahun 2002-2004 beberapa kinerja belum baik atau belum mampu mencapai target yang telah ditetapkan.

Darwanto (2009) menyatakan bahwa balanced scorecard membuat organisasi, termasuk organisasi publik, berfokus pada strategi, karena penerapan balanced scorecard memungkinkan semua unit dalam organisasi memberikan kontribusi secara terukur pada pelaksanan strategi organisasi. Balanced scorecard seyogyanya dikembangkan oleh setiap organisasi pemerintah untuk mempertajam perannya dalam menjalankan fungsi-fungsi pemerintahan, sehingga membedakannya dengan organisasi pemerintah lain. Tugas pengawasan oleh DPR terhadap pemerintah akan dipermudah jika instansi pemerintah memiliki strategi berbasis balanced scorecard. Perumusan balanced scorecard bukan suatu pekerjaan sekali jadi, melainkan tugas yang terus menerus, dengan setiap saat ada proses penyempurnaan dan yang terpenting adalah ia dimanfaatkan untuk mencapai visi dan misi organisasi.

Organisasi sektor publik yang digunakan dalam penelitian Fitria (2008) adalah Direktorat Jendral Pajak. Direktorat Jendral Pajak sebagai instansi pemerintah dibawah Departemen Keuangan memiliki visi "Menjadi Model Pelayanan Masyarakat yang Menyelenggarakan Sistem dan Manajemen Perpajakan Kelas Dunia dan Dibanggakan Masyarakat'. Untuk mengimplemen-tasikan visi tersebut, Direktorat Jendral Pajak menjabarkan beberapa misinya ke dalam misi fiskal, misi ekonomi misi politik dan misi kelembagaan. Dalam menjalankan tugas dan wewenangnya di daerah, Direktorat Jendral Pajak memiliki unit pelaksana, yaitu Kantor Pelayanan Pajak (KPP). KPP merupakan ujung tombak Direktorat Jendral Pajak yang berhubungan langsung dengan wajib pajak. KPP sangat menentukan baik buruknya citra Direktorat Jendral Pajak dimata masyarakat. Penelitian yang dilakukan terhadap KPP Klaten melalui empat pespektif Balanced scorecard diperoleh kesimpulan bahwa efektifitas organisasi ternyata dapat tercapai.

\section{Contoh Penerapan Balanced Scorecard di Kota Charlotte (AS)}

Berikut ini adalah konsep BSC yang diterapkan pada kota Charlotte (AS) sebagai organisasi pemerintah. Ada tujuh komponen dalam BSC Kota Charlotte, yaitu: visi, tema strategis (atau area fokus), prinsip strategis, perspektif, sasaran, kaitan, dan ukuran \& target.

1. Visi: Visi Kota Charlotte secara singkat adalah untuk menjadi "pilihan masyarakat untuk hidup, bekerja dan berekreasi".

2. Tema strategis atau area fokus: Dewan Kota menetapkan lima tema strategis atau area fokus sebagai strategi untuk mencapai visi kota: ketenteraman warga (community safety), kemandirian kota (city-within-city), kemajuan ekonomi (economic development), tranportasi (transportation) dan mereformasi birokrasi (restructuring government).

3. Prinsip strategis: Penerapan prinsip strategis adalah untuk membantu memastikan bahwa kota Charlotte akan menjadi pilihan masyarakat. Ada delapan prinsip strategis yang ditetapkan dan disebut Prinsip Pertumbuhan Cerdas (Smart Growth Principles), yaitu:

a. Mempertahankan kapasitas perencanaan penggunaan lahan

b. Mengupayakan keputusan penggunaan lahan yang efektif

c. Memperkuat masyarakat melalui lingkungan yang sehat

d. Merancang kota untuk mendukung kehidupan yang harmonis

e. Melindungi lingkungan

f. Memperluas aneka pilihan transportasi

g. Menggunakan investasi publik sebagai katalisator untuk mencapai hasil yang diinginkan

4. Perspektif: Dengan penekanan pada "keseimbangan", balanced scorecard Kota Charlotte menggunakan empat perspektif untuk menjawab kebutuhan pelayanan yang diinginkan oleh masyarakat.

a. Perspektif Pelanggan: Melayani pelanggan. Manajer kota harus mengetahui apakah pemerintah kota betul-betul memenuhi kebutuhan masyarakat. Mereka harus menjawab pertanyaan: Apakah organisasi menyediakan apa yang diinginkan oleh masyarakat?

b. Perspektif Proses Internal: Menyediakan pelayanan secara kompetitif. 
Manajer kota harus berfokus pada tugas penting yang memungkinkan mereka untuk memenuhi kebutuhan masyarakat. Manajer kota harus menjawab pertanyaan: Dapatkah pemerintah kota meningkatkan pelayanan dengan mengubah cara pelayanan itu disampaikan?

c. Perspektif Keuangan: Mengelola anggaran secara akuntabel.

Manajer kota harus berfokus pada bagaimana cara memenuhi kebutuhan pelayanan secara efisien. Mereka harus menjawab pertanyaan: Apakah pelayanan yang diberikan telah dilaksanakan dengan biaya yang rendah?

d. Perspektif Pembelajaran dan Pertumbuhan: Mengembangkan kapasitas karyawan.

Kemampuan organisasi untuk meningkatkan dan memenuhi permintaan masyarakat terkait secara langsung dengan kemampuan karyawan untuk memenuhi permintaan itu. Pemerintah kota harus menjawab pertanyaan: Apakah pemerintah kota menggunakan teknologi yang sesuai dan melakukan pelatihan karyawan untuk kemajuan yang berlanjut?

5. Sasaran

Kota Charlotte memilih 16 sasaran perusahaan untuk scorecard organisasinya. Setiap sasaran organisasi secara garis besar digambarkan sedemikian rupa sehingga ia memberikan konteks untuk mencapai apa organisasi itu dibentuk. Hubungan antara lima area fokus, empat perspektif dan 16 sasaran organisasi merupakan panduan bagi setiap unit dan karyawan dalam melaksanakan kegiatannya.

6. Kaitan

Sasaran yang strategis harus saling dihubungkan dalam suatu hubungan sebab-akibat. Misalnya, jika suatu organisasi memberikan karyawan dengan pelatihan yang perlu untuk "Mempromosikan Pembelajaran \& Pertumbuhan", maka organisasi itu akan dapat "Menyampaikan Pelayanan secara Kompetitif". Ini akan mempengaruhi kemampuan organisasi itu untuk "Meningkatkan Pelayanan bagi Masyarakat" yang pada akhirnya "Menyediakan Aneka Pilihan Pelayanan".

7. Ukuran \& Target

Untuk setiap sasaran strategis, ada satu set ukuran dan target strategis. Ini dijabarkan dalam rencana strategis untuk setiap area fokus.

\section{Penerapan Balanced Scorecard pada BPP Kemendagri}

Balanced Scorecard dapat diterapkan pada BPP Kemendagri, karena potensi-potensi yang sudah dimiliki. Hal ini dikarenakan BPP Kemendagri sudah melakukan perubahan mendasar dengan mereformasi dan mereposisi kelembagaannya. Pondasi yang telah ditetapkan adalah dengan melakukan perubahan dasar hukum yaitu menerbitkan Peraturan Menteri Dalam Negeri Nomor 20 Tahun 2011 tentang Pedoman Penelitian dan Pengembangan di Lingkungan Kementerian Dalam Negeri dan Pemerintahan Daerah dan Peraturan Bersama Menteri Negara Riset dan Teknologi dan Menteri Dalam Negeri Nomor 03 dan 36 Tahun 2012 tentang Penguatan Sistem Inovasi Daerah. Disamping itu telah dikeluarkan beberapa peraturan kebijakan yang terkait dengan operasional kelitbangan.

Untuk menerapkan balanced scorecard pada BPP Kemendagri yaitu harus berfokus pada strategi yang lebih bersifat hipotesis, suatu proses yang dinamis, dan merupakan pekerjaan setiap staf. BPP Kemendagri juga harus merasakan, mengadakan percobaan, belajar, dan menyesuaikan dengan perkembangan. BPP Kemendagri dapat berfokus pada strategi yang sudah dirumuskan, karena itu harus menerjemahkan strategi ke dalam terminologi operasional, menyelaraskan organisasi dengan strategi (dan bukan sebaliknya), memotivasi seluruh karyawan sehingga membuat strategi yang merupakan tugas setiap orang, menggerakkan perubahan melalui kepemimpinan eksekutif, dan membuat strategi sebagai suatu proses yang berkesinambungan.

Implementasi balanced scorecard pada BPP Kemendagri dengan merujuk pada konsep keseimbangan antara berbagai sudut pandang seperti, jangka waktu (pendek dan panjang), lingkup perhatian (intern dan ekstern) pengukuran kinerja eksternal dan kinerja internal, pengukuran kinerja masa lalu (finansial) dan pengukuran yang mendorong kinerja masa datang (non finansial), unsur objektivitas (pengukuran berupa hasil kuantitatif) dengan unsur subjektivitas (pengukuran pemicu kinerja yang membutuhkan pertimbangan/kualitatif), dan tujuan jangka pendek dan tujuan jangka panjang.

Contoh penerapan balanced scorecard, dapat diterapkan yaitu sebagaimana berikut:

1. Visi BPP Kemendagri

Terwujudnya Kebijakan Pemerintahan

Dalam Negeri yang Berkualitas Berdasarkan

Hasil Penelitian dan Pengembangan.

2. Tema strategis atau area fokus (misi)

a. Meningkatkan kualitas penelitian, pengkajian dan pengembangan di bidang pemerintahan daalam negeri.

b. Meningkatkan kualitas dan kuantitas sumber daya kelitbangan.

c. Memantapkan koordinasi dan kerjasama melalui pendayagunaan jejaring penelitian dan teknologi informasi di lingkungan Kementerian Dalam Negeri dan pemerintahan daerah, serta institusi penelitian dan pengembangan Kementerian/ LPND.

d. Meningkatkan kualitas pembinaan penelitian dan pengembangan bidang pemerintahan daerah melalui fasilitasi, supervisi, penyusunan norma, standar, prosedur, dan kriteria. 
e. Memantapkan kelembagaan dan ketatalaksanaan Badan Penelitian dan Pengembangan Kementerian Dalam Negeri dan Pemerintahan daerah.

3. Prinsip strategis

Prinsip strategis BPP Kemendagri sehubungan dengan telah ditetapkannya misi BPP Kemendagri di atas, maka telah ditetapkan tujuan sebagai penjabaran dari misi adalah sebagai berikut:

a. Meningkatkan kualitas kebijakan

Kementerian Dalam Negeri di bidang pemerintahan dalam negeri (T1).

b. Meningkatkan pendayagunaan hasil-hasil penelitian dan pengembangan (T2).

c. Meningkatkan kemampuan profesionalitas SDM Struktural, Peneliti, Perekayasa, Fungsional Khusus Lainnya, dan Fungsional Umum di lingkungan Kementerian Dalam Negeri dan Pemerintahan Daerah (T3).

d. Mengoptimalkan peran BPP dalam melaksanakan dan mengkoordinasikan kegiatan penelitian, pengkajian, dan pengembangan di lingkungan Kementerian Dalam Negeri (T4).

e. Mewujudkan kerjasama penelitian dan pengembangan dengan berbagai lembaga penelitian Kementerian/LPNK, pemerintahan daerah, dan negara/lembaga donor asing (T5).

f. Mengoptimalkan peran dan fungsi kelembagaan penelitian dan pengembangan daerah dalam peningkatan kualitas kebijakan pemerintahan dalam negeri (T6).

g. Mendorong penguatan kelembagaan, perbaikan substansi program dan peningkatan kualitas sumber daya penelitian dan pengembangan daerah (T7).

h. Meningkatkan dukungan manajemen dan dukungan pelayanan teknis lainnya dalam rangka menunjang tugas pokok dan fungsi BPP (T8).

4. Perspektif

a. Financial Perspective: How Do We Look To Stakeholders?

Pengukuran kinerja organisasi publik dari perspektif finansial di dalam balanced scorecard masih tetap dipertahankan, karena pengukuran kinerja keuangan sangat berharga di dalam menyarikan konsekuensikonsekuensi ekonomis yang dapat diukur dari tindakan-tindakan yang telah diambil oleh organisasi publik. Pengukuran kinerja keuangan menunjukkan apakah strategi suatu organisasi publik, penerapan, dan pelaksanaannya telah dapat memberikan kontribusi yang berarti bagi perbaikanperbaikan yang mendasar (bottom-line improvement). Selain itu, perspektif finansial dalam organisasi publik bertujuan untuk memberikan pelayanan yang efektif pada masyarakat dengan biaya jasa yang murah.

Menurut Kaplan dan Norton, siklus bisnis terbagi 3 tahap, yaitu: bertumbuh (growth), bertahan (sustain), dan menuai (harvest), di mana setiap tahap dalam siklus tersebut mempunyai tujuan finansial yang berbeda. Growth merupakan tahap awal dalam siklus. Pada tahap ini diharapkan kinerja organisasi pemerintah memiliki produk yang dirasa sangat potensial dan meningkatkan layanan, membangun serta mengembangkan fasilitas yang menunjang produksi, investasi pada sistem, infrastruktur dan jaringan distribusi yang akan mendukung terbentuknya hubungan kerja secara menyeluruh dalam mengembangkan hubungan yang baik dengan pihak yang berkepentingan. Secara keseluruhan tujuan finansial pada tahap ini adalah mengukur persentase tingkat pertumbuhan pendapatan atau investasi, dan tingkat pertumbuhan produk dari organisasi.

Tahap selanjutnya adalah sustain (bertahan), di mana pada tahap ini timbul pertanyaan mengenai akan ditariknya investasi atau melakukan investasi kembali dengan mempertimbangkan tingkat pengembalian yang mereka investasikan. Pada tahap ini tujuan finansial yang hendak dicapai adalah untuk memperoleh keuntungan. Berikutnya suatu usaha akan mengalami suatu tahap yang dinamakan harvest (menuai), di mana suatu organisasi atau badan usaha akan berusaha untuk mempertahankan bisnisnya. Tujuan finansial dari tahap ini adalah untuk untuk meningkatkan aliran kas dan mengurangi aliran dana.

Dalam konteks perspektif finansial untuk BPP Kemendagri, kinerja dapat diukur dengan menggunakan analisis realisasi anggaran, tingkat efisiensi dan efektifitas penggunaan anggaran, dan analisis vertikal. Implementasinya dengan melakukan langkah atau tahapan yang ditempuh melalui tahapan tumbuh (growth) lebih dahulu. Dalam tahapan tumbuh ini, kinerja BPP Kemendagri harus melahirkan produk kelitbangan yang potensial. Untuk mendapatkan produk tersebut maka BPP Kemendagri harus melakukan program investasi organisasi dengan menata komponen organisasi baik sumber daya manusia, struktur, tata laksana maupun sarana dan prasarana organisasi. Dalam tahap ini BPP Kemendagri harus dapat mengukur persentase tingkat pertumbuhan pendapatan atau investasi dan tingkat pertumbuhan produk dari organisasi. 
Kemudian secara berkesinambungan memasuki tahap (sustain) bertahan yang lebih cenderung melakukan evaluasi terhadap tahap pertumbuhan dan mempertimbangkan langkah menghentikan investasi dan menata ulang atau melanjutkan investasi organisasi. Ketika dirasakan hasil evaluasi sudah mulai mendapatkan hasil, maka selanjutnya masuk ke dalam tahap (harvest) menuai, dimana investasi yang dilakukan organisasi telah memperoleh keuntungan. Karena tahapan ini merupakan siklus dan berkesinambungan, maka tahapan selanjutnya adalah kembali lagi ke dalam tahap (growth) tumbuh untuk terus menerus meningkatkan kinerja BPP Kemendagri.

b. Customer and Stakeholder Perspective:

How Do Customers See Us?

Organisasi publik harus memiliki orientasi untuk mengutamakan kesejahteraan dan kepuasan customer dan stakeholder-nya, dalam hal ini masyarakat. Oleh karena itu, balanced scorecard menuntut para pimpinan organisasi pemerintah untuk dapat menerjemahkan misi organisasi publik mengenai pelayanan kepada masyarakat secara umum ke dalam suatu pengukuran spesifik yang mencerminkan faktor-faktor penting bagi masyarakat.

Perhatian masyarakat terhadap organisasi cenderung tertuju pada empat faktor penting yaitu time, quality, performance and service, dan cost. Lead time mengukur waktu yang dibutuhkan oleh organisasi publik untuk memenuhi kebutuhan masyarakat. Quality mengukur tingkat kegagalan pelayanan yang dirasakan dan dinilai sendiri oleh masyarakat. Quality juga dapat digunakan untuk mengukur ontime delivery, yaitu keakurasian dari perkiraan penyelesaian layanan. Kombinasi performance and service mengukur bagaimana pelayanan yang diberikan oleh organisasi publik memberi kontribusi dalam penciptaan nilai bagi masyarakat. Untuk memposisikan balanced scorecard di dalam lingkungan kerja, masyarakat harus menyatakan tujuan (goals) bagi time, quality, dan performance and service dan kemudian menerjemahkan tujuan tersebut ke dalam suatu sistem pengukuran yang spesifik.

BPP Kemendagri perlu menempatkan lembaganya agar lebih profesional. Dalam perspektif pandangan customer-nya BPP Kemendagri adalah Menteri Dalam Negeri melalui komponenkomponen di lingkungan Kementerian Dalam Negeri. Sedangkan stakeholder-nya
BPP Kemendagri adalah pemerintah daerah Provinsi maupun kabupaten/kota sebagai pihak yang berkepentingan, kementerian dan lembaga non kementerian lainnya serta secara umum adalah masyarakat.

BPP Kemendagri perlu membuat suatu sistem pengukuran yang spesifik agar dapat menerjemahkan tujuan dalam kategori time, quality, dan performance and service dari kinerja yang dihasilkan BPP Kemendagri. Perspektif time adalah ukuran waktu yang tepat atau justru lebih cepat dalam menghasilkan produk kelitbangan sesuai yang dibutuhkan customer dan stakeholder. Perspektif quality diberlakukan terhadap proses dan produk kelitbangan yang berkualitas bagi customer dan stakeholder. Kemudian perspektif performance and service adalah peningkatan kualitas pelayanan dan kinerja yang dilakukan dan diberikan oleh BPP Kemendagri kepada customer and stakeholder. Langkah awal menerapkan perspektif ini dapat dilakukan dengan penerapan Standard Operasional Procedure (SOP) terhadap semua kegiatan yang ada di BPP Kemendagri. Kemudian untuk penerapan lebih lanjut, BPP Kemendagri harus mampu mengimplementasikannya menjadi budaya kerja.

c. Internal Business Process Perspective: What Must We Excel at?

Pengukuran internal dalam balanced scorecard berasal dari proses bisnis yang mempunyai pengaruh paling besar terhadap kepuasan masyarakat (customer satisfaction) yaitu misalnya faktor-faktor yang mempengaruhi cycle time, quality, employee skills, and productivity. Dalam Internal Business Process Perspective ini, organisasi publik dituntut untuk dapat mengidentifikasi proses bisnis internal mana yang penting dan mengandung nilai-nilai yang diinginkan oleh pelanggan, yang harus dilakukan dengan sebaik-baiknya oleh organisasi publik.

Di dalam perspektif ini balanced scorecard akan memasukkan proses inovasi yaitu suatu proses perancangan dan pengembangan produk, dimana organisasi pemerintah/publik akan dimotivasi untuk mempunyai kemampuan bersaing jangka panjang dalam rangka untuk memuaskan masyarakat di masa mendatang. Setelah berinovasi, organisasi publik harus melakukan perbaikan pada proses operasionalnya. Proses terakhir yang harus dilakukan oleh organisasi publik untuk memperbaiki proses bisnis internalnya adalah mengukur proses pelayanannya.

BPP Kemendagri adalah lembaga 
yang memiliki tugas pokok dan fungsi yang spesifik. Spesifikasi ini diatur dalam peraturan perundang-undangan, bahwa kelitbangan pemerintahan dalam negeri di lingkungan Kemendagri merupakan kewenangan dan tanggung jawab BPP Kemendagri. Spesifikasi ini merupakan kelebihan yang dimiliki BPP Kemendagri. Dalam perspektif proses bisnis internal, BPP Kemendagri harus memanfaatkan kelebihan yang dimilikinya menjadi sesuatu yang dapat memberikan kepuasan kepada user dan stakeholder. Untuk itu perlu dipertimbangkan faktor cycle time, quality, employee skills, and productivity dari kegiatan kelitbangan BPP Kemendagri. Penerapan inovasi dalam melaksanakan kegiatan kelitbangan perlu dilakukan secara terus menerus, sehingga selalu ada perubahan yang posistif dan menghasilkan perbaikan hasil kelitbangan. Secara internal, BPP Kemendagri perlu melakukan terobosan inovatif terhadap siklus waktu yang dibutuhkan dalam proses kegiatan kelitbangan, dengan mencari alternatif waktu yang lebih cepat dan lebih baik.

Perbaikan kualitas (quality) terhadap produk kelitbangan harus ada sentuhan inovasi yang dilakukan BPP Kemendagri, baik dari sisi proses, hasil ataupun dampak yang dihasilkan produk kelitbangan. Disamping itu peningkatan kompetensi sumber daya manusia kelitbangan harus ditingkatkan secara berkesinambungan. Langkah-langkah strategis dan terobosan inovatif dalam mengembangkan profesionalitas sumber daya manusia kelitbangan menjadi sebuah keharusan dalam perspektif bisnis internal BPP Kemendagri. Kemudian semua produk yang dihasilkan BPP Kemendagri harus menghasilkan produk yang sesuai dengan harapan user dan stakeholder. Bahkan dalam perspektif ini, dalam setiap produk kelitbangan perlu diberikan sentuhan inovatif. Sehingga user and stakeholder tidak hanya menerima produk yang sesuai harapan, tapi juga mendapatkan kepuasan yang lebih.

d. Employee and Organization Capacity Perspective: Can We Continue to Improve and Create Value?

Di dalam pengukuran yang berdasar pada perspektif pelanggan dan perspektif proses bisnis internal, balanced scorecard mengidentifikasi parameter-parameter yang dianggap paling penting oleh organisasi publik untuk dapat melayani masyarakat dengan baik. Tetapi sasaran untuk mencapai kepuasan masyarakat tersebut terus menerus berubah. Di dalam perspektif ini, organisasi publik memandang tiga faktor utama yaitu aparat, sistem, dan prosedur organisasi. Ketiga faktor ini yang memegang peranan dalam pertumbuhan jangka panjang perusahaan. Oleh sebab itu organisasi publik harus melakukan investasi dalam ketiga faktor di atas untuk menjamin tercapainya tujuan organisasi publik.

BPP Kemendagri perlu membangun dan mengembangkan kapasitas organisasinya secara terus menerus. Indikator yang ada dalam pembangunan kapasitas (capacity building) yaitu tingkatan sumber daya manusia (aparat), tingkatan kelembagaan dan tingkatan sistem, harus selalu siap berubah, semakin hari menjadi semakin lebih baik, dapat menjawab tantangan jaman, dan memenuhi tuntutan customer and stakeholder dan secara umum kepada masyarakat.

Untuk menjaga kesinambungan sumber daya manusia kelitbangan yang dimiliki, harus ada kaderisasi yang terprogram. Pembinaan karier dan profesional bagi sumber daya manusia kelitbangan harus dijaga pelaksanaannya, dengan meningkatkan kapasitasnya dari mulai siklus rekruitmen sampai dengan pengembangan profesionalitas sumber daya manusia kelitbangan secara berkesinambungan. Dalam tataran sistem harus ada interaksi yang saling bersinergi dari semua unit organisasi internal maupun pihak-pihak yang berkepentingan. Mekanisme prosedur organisasi harus dilakukan penataan terus menerus terhadap kelembagaan kelitbangan, baik secara mendasar dalam tataran hukum maupun implementasi pengorganisasiannya.

5. Sasaran

Adapun sasaran yang akan dicapai berdasarkan tujuan yang telah ditetapkan adalah sebagai berikut:

a. Untuk mencapai tujuan pada T1, maka sasaran yang ditetapkan yaitu:

1) Meningkatnya kualitas penyelenggaraan tugas dan fungsi Pusat-Pusat Litbang di lingkungan BPP Kemendagri.

2) Meningkatnya keterlibatan dan keikutsertaan BPP dalam perumusan kebijakan strategis lingkup Kementerian Dalam Negeri.

b. Untuk mencapai tujuan pada T2, maka sasaran yang ditetapkan yaitu:

1) Meningkatnya pemanfaatan hasil kelitbangan bagi perumusan kebijakan pemerintahan dalam negeri.

2) Meningkatnya publikasi hasil-hasil kelitbangan yang berkualitas. 
c. Untuk mencapai sasaran pada T3, maka sasaran yang ditetapkan yaitu:

1) Meningkatnya kinerja pejabat struktural, pejabat Fungsional peneliti, Perekayasa dan fungsional lainnya.

2) Tersedianya SDM Struktural dan Pejabat Fungsional Peneliti dan Perekayasa yang profesional dan berkualitas.

d. Untuk mencapai sasaran pada T4, maka sasaran yang ditetapkan yaitu:

1) Meningkatnya hasil-hasil kelitbangan, sebagai bahan kebijakan strategis lingkup Kementerian Dalam Negeri.

2) Meningkatnya koordinasi kegiatan kelitbangan lingkup Kementerian Dalam Negeri.

e. Untuk mencapai sasaran pada T5, maka sasaran yang ditetapkan yaitu:

1) Meningkatnya sinergitas program dan kegiatan kelitbangan melalui koordinasi dan jejaring antara BPP Kemendagri dan Pemerintahan Daerah.

2) Meningkatnya kerjasama penelitian dan pengembangan dengan berbagai lembaga penelitian Kementerian/LPNK, pemerintah daerah, dan negara/ lembaga donor asing.

f. Untuk mencapai sasaran pada T6, maka sasaran yang ditetapkan yaitu:

1) Meningkatnya peran lembaga litbang daerah sebagai think tank penyelenggaraan pemerintahan dalam negeri.

2) Meningkatnya kapasitas lembaga litbang daerah sebagai sumber data dan informasi bagi penyelenggaraan pemerintahan dalam negeri.

g. Untuk mencapai sasaran pada T7, maka sasaran yang ditetapkan yaitu:

1) Meningkatnya kapasistas lembaga litbang daerah.

2) Meningkatnya kualitas dan kuantitas sumber daya kelitbangan daerah.

h. Untuk mencapai tujuan pada T8, maka sasaran yang ditetapkan yaitu:

1) Meningkatnya kualitas perencanaan, pelaksanaan, monitoring, evaluasi, fasilitasi, kerjasama dalam menunjang tugas dan fungsi BPP.

2) Meningkatnya tertib administrasi kepegawaian, ketatausahaan, keuangan, sarana dan prasarana perkantoran BPP.

6. Kaitan

Sasaran yang strategis harus saling dihubungkan dalam suatu hubungan sebab-akibat. . Jika BPP Kemendagri memberikan karyawan dengan pelatihan yang perlu untuk "Mempromosikan Pembelajaran \& Pertumbuhan", maka BPP Kemendagri akan dapat "Menyampaikan Produk Kelitbangan secara Kompetitif'. Ini akan mempengaruhi kemampuan organisasi itu untuk "Meningkatkan Produk Kelitbangan bagi Kemendagri, Pemda dan Masyarakat
Pada Umumnya" yang pada akhirnya "Menyediakan Aneka Pilihan Produk Kelitbangan”.

7. Ukuran \& Target

Untuk setiap sasaran strategis, ada satu set ukuran dan target strategis. Ini dijabarkan dalam rencana strategis BPP Kemendagri untuk setiap area fokus (misi)

\section{PENUTUP}

Balanced scorecard adalah sebuah cara pandang baru bagaimana suatu organisasi akan dapat lebih baik lagi dikelola. Balanced scorecard merupakan bagian dari sistem manajemen strategis, yang perlu dirumuskan oleh setiap organisasi, agar dapat mencapai visi dan misinya secara efektif. Balanced scorecard memberikan prosedur bagaimana tujuan organisasi dirinci ke dalam sasaran-sasaran dalam berbagai perspektif secara lengkap, dengan ukuran-ukuran yang jelas.

Balanced scorecard merupakan mekanisme untuk membuat organisasi, berfokus pada strategi, karena penerapan balanced scorecard memungkinkan semua unit dalam organisasi memberikan kontribusi secara terukur pada pelaksanan strategi organisasi. Oleh karena itu balanced scorecard seyogyanya dikembangkan oleh setiap organisasi pemerintah untuk mempertajam perannya dalam menjalankan fungsifungsi pemerintahan, sehingga pencapaian tujuan menjadi lebih efektif. Disamping itu peran dari semua unit dalam organisasi pemerintah dapat dimaksimalkan kontribusinya.

BPP Kemendagri sebagai organisasi pemerintah yang sedang mereformasi dan mereposisi kelembagaannya, menjadi sangat strategis dalam memfungsikan perannya di lingkungan Kemendagri maupun pemerintahan dalam negeri. Penggunaan BSC menjadi sebuah kebutuhan, sebagai alternatif utama mengingat tantangan peran strategis BPP Kemendagri ke depan.

Meskipun begitu, perumusan balanced scorecard bukan suatu pekerjaan sekali jadi, melainkan tugas yang harus dilakukan terus menerus, dengan setiap saat ada proses penyempurnaan dan yang terpenting adalah ia dimanfaatkan untuk mencapai visi dan misi organisasi.

\section{DAFTAR PUSTAKA}

Anderson, L K., dan Horald M. Sollenberger. 1992. Managerial Accounting 8th Edition. Cincinnati, Ohio: South Western Publishing.

Anthony, Robert N. dan Vijay Govindarajan. 2005. Management Control Systems. 11th Edition. Jakarta: Salemba Empat.

Astri, W.W. 2009. Laporan Akuntabilitas Kinerja Pemerintah (LAKIP). http://gitacintanyawilis. blogspot.com/2009/11/laporan-akuntabilitaskinerja (diakses pada Oktober 2010).

Baihaqi. 2006. Pilih Yang Mana: Six Sigma, Lean, TQM, ISO? Htpp://baihaqi/wordpress.com (diakses pada 
Oktober 2010).

Budiarti, Isniar. 2004. Balanced Scorecard sebagai Alat Ukur Kinerja dan Alat Pengendali Sistem Manajemen Strategis. Majalah Ilmiah Unikom 6: 51-59.

Darwanto, H. 2009. Balanced Scorecard untuk Organisasi Pemerintah. http://www.bappenas.go.id/node/48/ 2294/balanced-scorecard-untukorganisasipemerintah (diakses pada Oktober 2010).

Edition, Thomson. Helmi, S. 2009. Rasio-Rasio keuangan Perusahaan. http://shelmi. wordpress.com/2009/03/ 04/rasio-E2\%80\%93-rasiokeuangan-perusahaan/ (diakses pada September 2010).

Hansen, Don R, dan Maryanne M. Mowen. 2005. Management Accounting. $7^{\text {th }}$.

Horngren, Charles T., Walter T. Harrison Jr., dan Michael A. Robinson. 1994. Principles Of Financial And Management Accounting. Englewood Cliffs, New Jersey: Prentice Hall International Inc.

Hsieh, H.-F., dan S.E.Shannon. 2005. Three Approaches To Qualitativen Content Analysis. Qualitative Health Research, 15(9): 1277-1288.

Ikopin. 2008. Analisis Faktor-Faktor yang Mempengaruhi Kinerja Karyawan. http://one.indoskripsi.com. (diakses pada November 2010).

Imelda, R.H.N. 2004. Implementasi Balanced Scorecard pada Organisasi Publik. Jurnal Akuntansi dan Keuangan 6(2): 106-122.

Johannes. 2005. Balanced Scorecard Konsep dan Implementasi sebagai Strategi Perusahaan. Unpublish

Kaplan, Robert S. dan David P. Norton, 1996. The Balanced Scorecard: Translating Strategy Into Action. Harvard Business School Press: 150-161

Kaplan, Robert S. dan David P. Norton, 1996. Using The Balanced Scorecard As A Strategic Management System. Harvard Business Review.

Kaplan, Robert S. dan David P. Norton. 1992. The Balanced Scorecard -Measures That Drive Performance, Harvard Business Review: 71-79.

Kaplan, Robert S. dan David P. Norton. 1993. Putting The Balanced Scorecard To Work. Harvard Business Review.

Killough, Larry N. dan Wayne E. Leininger. 1994. Cost Accounting: For Managerial Decision Making. 1st Edition California: Dickenson Publishing Company Inc.

Maciariello, Joseph A. 1991. Management Control System. Englewood Cliffs, New Jersey: Prentice Hall International Inc.

Mahmudi. 2007. Manajemen Kinerja Sektor Publik. Yogyakarta: UPP STIM YKPN.

Mangkuprawira. 2009. Komitmen Karyawan dan Budaya Kerja. http://ronawajah.wordpress. com (diakses pada Januari 2010).

Mathis, Robert L. dan John H. Jackson. 2001. Manajemen Sumber Daya Manusia. Edisi 1. Jakarta: Salemba Empat.

Milkovitch, George T. dan John W. Boudreau. 1994. Human Resource Management. 6th Edition, Homewood, Illinois: Richard D. Irwin Inc.

Mulyadi dan Setyawan, J. 2001. Sistem Perencanaan dan Pengendalian Manajemen: Sistem Pelipatgandaan
Kinerja Keuangan Perusahaan. Jakarta: Salemba Empat.

Munawir, S. 2008. Analisa Informasi Keuangan. Edisi Keempat. Yogyakarta: Liberty.

Natha, K.S. 2008. Total Quality Management sebagai Perangkat Manajemen Baru untuk Optimisasi. Buletin Studi Ekonomi 13 (1): 1-12

Niviari, N. 2008. Six Sigma, Balance Scorecard, dan Kaitannya dengan Audit Manajemen. Audit Jurnal Akuntansi dan Bisnis 3(1)

Ostrenga, R. Michael; Terrence R. Ozan; Robert D. Mc. Ilhattan; dan Marcus D. Harwood. 1992. The Earnst And Young Guide To Total Cost Management. New York: John Wiley And Son.

Rahmawati, A.D., Suwitri, dan Maesaroh, 2006. Analisis Kinerja Organisasi Publik dengan Metode "Balanced Scorecard". Dialog Jurnal Ilmu Administrasi dan Kebijakan Publik 3(1):78-88.

Raymond McLoad, Jr. Sistem Informasi Manajemen. Jakarta: PT. Prenhallindo.

Rivai, V. dan A. Fawzi, M.. Basri. 2004. Performance Appraisal: Sistem yang Tepat untuk Menilai Kinerja Karyawan dan Meningkatkan Daya Saing Perusahaan. Jakarta: PT Rajagrafindo Persada.

Robbins, S.P. 1997. Perilaku Organisasi: Konsep Kontroversi dan Aplikasi. Edisi Bahasa Indonesia. Jakarta: Prenhallindo.

Ross, Westerfeld, Jordan. 2009. Pengantar Keuangan Perusahaan. Corporaten Finace Fundamentals. Jakarta: Salemba Empat.

Sony Yuwono, et.al. 2003. Petunjuk Praktis Penyusunan Balanced Scorecard.

Suharsono, E.G. 2005. Kerangka Balance Scorecard dalam Menciptakan Keunggulan Bersaing Bagi Perusahaan. Unpublished

Sulastri, A. 2003. Penerapan Balanced Scorecard sebagai Sistem Penilaian Kinerja Pada Rumah Sakit Islam Surakarta Skripsi, Unpublished, Fakultas Ekonomi Universitas Sebelas Maret

Timpe, A.D. 1993. Kinerja. Cetakan Kedua. Jakarta: PT. Gramedia Asri Media.

Vincent Gaspersz. 2002. Sistem Manajemen Kinerja Terintegrasi Balanced Scorecard dengan Six Sigma.

Weygandt, Jerry J.; Donald E. Kieso; dan Terry D. 2007. Waffield, Intermediate Accounting. $12^{\text {th }}$ Canada: Edition. John Wiley \& Sons, Inc.

Widjaja T., Amin. 2002. Memahami Balanced Scorecard.

Wild, John J; K.R. Subranyaman; dan Robert F Halsey, 2005. Financial Statement Analysis. Jakarta: Salemba Empat.

Yuli. 2006. TQM, Six Sigma dan Balanced Scorecard http://kucingmeong.multiply.com (diakses pada November 2010). 
200 | Jurnal Bina Praja | Volume 4 No. 3 September 2012| 189 - 200 